\title{
Long-Term Controlled Field Experiment on the Competition Between Two Species of Biomphalaria (Mollusca, Basommatophora), the Snail Vectors of Schistosoma mansoni in Northeastern Brazil
}

\author{
Estudo Experimental de Campo sobre a Competição entre Duas \\ Espécies de Biomphalaria (Mollusca, Basommatophora), Vetores do \\ Schistosoma mansoni no Nordeste do Brasil
}

\author{
Constança S. Barbosa ${ }^{1}$ \\ Frederico S. Barbosa ${ }^{2}$ \\ Francisco Arruda ${ }^{1}$
}

BARBOSA, C. S.; BARBOSA, F. S. \& ARRUDA, F. Long-Term Controlled Field Experiment $n$ the Competition Between Two Species of Biomphalaria (Mollusca, Basommatophora), the Snail Vectors of Schistosoma mansoni in Northeastern Brazil. Cad. Saúde Públ., Rio de Janeiro, 9(2): 170-176, Apr/Jun, 1993.

A long-term controlled field experiment on the interactions of the populations of Biomphalaria glabrata (target population) and B. straminea (competitor) was carried out in the county of Alhandra, state of Paraíba, Brazil, during the period 1980 through 1989. Results obtained in the current paper show that the snail B. straminea has strong competitive advantages over $\mathrm{B}$. glabrata. In six out of nine streams the native population of $\mathrm{B}$. glabrata were totally excluded and replaced by B. straminea. There is evidence showing that seasonal dryness has marked influence on the phenomenon studied in this paper. In all the streams were B. straminea already predominated, return of $\mathrm{B}$. glabrata was never observed.

Key words: Biomphalaria; Schistosomiasis; Biological Control; Competitive Behavior

\section{INTRODUCTION}

Two snail species are known to act as intermediate hosts of Schistosoma mansoni in Northeastern Brazil: Biomphalaria glabrata (Say) and B. straminea (Dunker). These freshwater planorbid snails living in limited physical environment are subject to all sorts of ecological pressures. These snails live in a wide variety of habitats, particularly in shallow and slow running waters. These

\footnotetext{
${ }^{1}$ Centro de Pesquisas Aggeu Magalhães da Fundação Oswaldo Cruz. Campus da Universidade Federal de Pernambuco, Recife, PE, 50670-420, Brasil.

${ }^{2}$ Escola Nacional de Saúde Pública, Fundação Oswaldo Cruz. Rua Leopoldo Bulhões, 1480, Rio de Janeiro, RJ, 21041-210, Brasil.
}

freshwater molluscs thrive in relatively narrow ranges of temperature, saline concentration, and other environmental conditions. They occupy the second trophic level although can live as saprophytes. The aquatic vegetation is an important suitable factor for the maintenance of their colonies, serving as physical support, shelting and feeding, rather than as oxigen producer.

In Northeastern Brazil, variations in temperature are too small and the important factor interfering with the life cycle of the snails is the rainfall system which substantially affects the reproductivity cycles and the population dynamics of these snails (Olivier \& Barbosa, 1955a, 1955b).

When the habitat dries, the exposed snails lying on the soil gradually die from the 
excessive heat or are eaten by predatory animals. The surviving the dry season are those which were protected somehow by debris, dead leaves, and so on. Growth of low vegetation in the dried former foci produces a more favorable microclimate for the aestivating snails. $B$. glabrata and $B$. straminea (Barbosa \& Olivier, 1958) can survive several months out of water, but there is evidence showing that $B$. straminea is more resistant to desiccation than $B$. glabrata (Barbosa et al., 1985).

The above species of vector snails have a well-known distribution in Northeastern Brazil. B. straminea is found everywhere, whereas $B$. glabrata is limited to the litoral and forest zones (Paraense, 1977). The geographical distribution of these species in Northeastern Brazil is well-known mainly through two extensive snail surveys carried out in the region by Lucena (1963) and Barbosa \& Figueiredo (1969). Although they are sympatric species, they are almost never found in the same body of water (Barbosa, 1962 and Barbosa \& Olivier, 1958). Paraense $\&$ Deslandes (1955) refer to the coexistence of B. glabrata and B. straminea in the state of Minas Gerais, mentioning however the infrequence of such occurrence.

Wright (1968), referring to Brazil, suggested that the "...competitive exclusion should be considered one of the factors that influence the distribution of the population of the three Biomphalaria species studied".

Barbosa (1973) had the unique opportunity of following the natural introduction of a small colony of $B$. straminea into a limited area inhabited exclusively by $B$. glabrata in the outskirts of the town of Recife, Brazil. In this "natural experiment" $B$. glabrata was displaced by $B$. straminea at the end of a three year observation period.

More recently, Guyard \& Pointier (1979) observed that in Martinique B. glabrata, a rare species at present, is being naturally replaced by $B$. straminea. The same phenomenon seems to occurs in certain areas of Northeastern Brazil (Barbosa, 1981; Barbosa-Figueiredo, 1989a, 1989b).

Michelson \& Dubois (1979), working under laboratory conditions, confirmed the field observations of Barbosa (1973), mentioning that $B$. straminea seems to be a dominant species and under certain circumstances may replace $B$. glabrata. $B$. straminea has shown great vagility and aggressiveness in invading new territories occupied by $B$. glabrata (Michelson \& Dubois, 1979; Barbosa et al., 1984).

Teles (1988) found B. straminea spreading in several regions of the state of São Paulo, and Meier-Brook (1974) first recorded that species in Hong-Kong.

In the current paper a long-term controlled field experiment on the interactions of the populations of $B$. glabrata $\times$ B. straminea is described.

\section{THE STUDY AREA}

The current experiment was carried out in the county of Alhandra, state of Paraíba, Northeastern Brazil, covering the small valley of the Junçara river and their ten tributary streams. The valley is limited on western side by a chain of low level hills. On the eastern side, the area is continued through a low brackish water mangrove formation leading to the Atlantic Ocean.

This very particular enclosured area was found to be extremely suitable for the development of such type of experiment.

Alhandra is situated in the humid coastal forest zone of Northeastern Brazil, formerly occupied by tropical forests. In this area the climate is hot and humid. The annual temperature averages about $27^{\circ} \mathrm{C}$. The most important factor disturbing the freshwater habitat in the region is the rainfall distribution. There is a marked seasonal cycle of rains. Over 80 per cent of this rain falls in the period from March through August, which is called winter. During the dry season, from September through February, many pools and streams dry up gradually. In the winter, low areas are flooded and the streams are full. Water recedes gradually after the rain season and by December some of the water bodies are totally or partially dry. 


\section{METHODS}

This study was carried out from November 1980 to November 1989.

The area is well-known to our research group for about 30 years. During this long period, intermittent snail collections made in the area revealed that $B$. glabrata was the only planorbid species found. Other snails belonging to the families Physidae and Ampullariidae were present in diversified numbers as usual inhabitants of freshwater habitats.

The Junçara valley comprising the main river and ten tributaries was taken as experimental area. The Popocas River, located northern of the Junçara valley, was kept as comparison area.

During the period of one year $(1980$ 1981) a pre-control study on the snail population living on both experimental and control areas was carried out. Three snail surveys made during the above period confirmed that $B$. glabrata was the only Biomphalaria species inhabiting the Junçara and Popocas valleys, as well as the only one living around the studied areas.

The natural population of $B$. glabrata living in the Junçara valley was the target species, while $B$. straminea, R3 strain, was used as competitor. This decision was taken on the basis of our previous knowledge on the competitive superiority of $B$. straminea (Barbosa, 1973).

The R3 B. straminea, originated from Sete Lagoas, state of Minas Gerais, Brazil, is a pure albino strain resistant to the infection with Schistosoma mansoni. This strain was sent to Dr. C. S. Richards (Biomedical Research Institute, Rockville, MD USA) by Dr. W. L. Paraense (Fundação Oswaldo Cruz, Rio de Janeiro, Brazil). The albino stock was obtained through exposure to infection and selection of the original strain (Richards, in letter to senior author, 1982). Mass cultivation of the R3 strain was obtained in the laboratory according to technique developed by Barbosa (1992).

Snails were collected by means of standardized scoops in fixed collecting field stations covering $20 \%$ of each stream. Snail counting was made by trained field workers and referred as snail/minute/man (Olivier \& Schneiderman, 1956). Snails were identified and counted in the field and then replaced to their original sites. The distinction between the two species was facilitated by the different skin colors exhibited by each snail species. The absence of pigment in the skin of B. straminea made it look red-collored, while B. glabrata kept its black appearence.

The experimental phase of the current study was carried out in the period of November 1981 through November 1989. At that time, the competitor snails (B. straminea, R3 strain) began to be introduced in the collecting stations of the experimental area.

The number of snails introduced varied according to the size of the stream. A total of 166,520 snail specimens were introduced during the whole period of the experimental phase, as follows: 2,800 in 1981 (2-month period); 20,800 in $1982 ; 26,420$ in 1983 ; 39,700 in $1984 ; 32,100$ in $1985 ; 11,000$ in 1986 ; 8,600 in 1987 ; 12,700 in 1988 ; and 12,400 in 1989 . Obviously the snail competitor was not introduced in the control area.

Snail collections were initially made at intervals of three months, and latter at sixmonth intervals.

The introductions of the competitor snails were made just after each routine snail collection. In the streams where $B$. straminea populations were considered consolidated, the introduction of the R3 strain was discontinued.

\section{RESULTS}

Table 1 and Figure 1 show the results of the evaluations carried out in 12 streams of both the experimental and control areas in the period of November 1981 to November 1989.

Streams 5 and 9 have been deviated from their original course and connected to other streams of the area. For this reason they could not be evaluated.

Six out of the remaining nine streams (number 2, 3, 4, 8, 10 and 11) had their 
TABLE 1. Snail Average per Stream in the Period 1981 - 1989, Alhandra, State of Paraíba, Brazil

\begin{tabular}{|c|c|c|c|c|c|c|c|c|c|c|c|c|c|c|c|c|c|c|}
\hline \multirow{2}{*}{$\begin{array}{l}\text { Stream } \\
\text { no. }\end{array}$} & \multicolumn{2}{|c|}{1981} & \multicolumn{2}{|c|}{1982} & \multicolumn{2}{|c|}{1983} & \multicolumn{2}{|c|}{1984} & \multicolumn{2}{|c|}{1985} & \multicolumn{2}{|c|}{1986} & \multicolumn{2}{|c|}{1987} & \multicolumn{2}{|c|}{1988} & \multicolumn{2}{|c|}{1989} \\
\hline & $\mathrm{Bg}$ & Bs & $\mathrm{Bg}$ & Bs & $\mathrm{Bg}$ & Bs & $\mathrm{Bg}$ & Bs & $\mathrm{Bg}$ & Bs & $\mathrm{Bg}$ & Bs & $\mathrm{Bg}$ & Bs & $\mathrm{Bg}$ & Bs & $\mathrm{Bg}$ & Bs \\
\hline 1 & 137 & 0 & 192 & 2 & 76 & 0 & 49 & 4 & 74 & 1 & 46 & 0 & 84 & 0 & 113 & 0 & 40 & 0 \\
\hline 2 & 46 & 0 & 254 & 0 & 140 & 3 & 15 & 62 & 7 & 30 & 0 & 29 & 0 & 106 & 0 & 26 & 0 & 22 \\
\hline 3 & 115 & 0 & 12 & 202 & 0 & 16 & 0 & 23 & 0 & 37 & 0 & 12 & 0 & 16 & 0 & 14 & 0 & 48 \\
\hline 4 & 133 & 0 & 22 & 2 & 0 & 14 & 0 & 48 & 0 & 78 & 0 & 414 & 0 & 203 & 0 & 118 & 0 & 58 \\
\hline 5 & 32 & 0 & 30 & 0 & 43 & 1 & 4 & 0 & 1 & 3 & - & - & - & - & - & - & - & - \\
\hline 6 & 13 & 0 & 43 & 0 & 16 & 0 & 2 & 0 & 2 & 0 & 7 & 0 & 5 & 0 & 15 & 23 & 3 & 0 \\
\hline 7 & 69 & 0 & 54 & 2 & 47 & 1 & 24 & 5 & 10 & 11 & 15 & 20 & 0 & 54 & 30 & 3 & 14 & 19 \\
\hline 8 & 47 & 0 & 18 & 3 & 12 & 27 & 2 & 26 & 0 & 8 & 0 & 18 & 0 & 28 & 0 & 0 & 0 & 10 \\
\hline 9 & 31 & 0 & 23 & 0 & 30 & 0 & 6 & 0 & - & - & - & - & - & - & - & - & - & - \\
\hline 10 & 20 & 0 & 12 & 29 & 0 & 21 & 0 & 9 & 0 & 68 & 0 & 70 & 0 & 27 & 0 & 20 & 0 & 25 \\
\hline 11 & 27 & 0 & 9 & 0 & 7 & 10 & 21 & 32 & 6 & 30 & 0 & 24 & 0 & 22 & 0 & 9 & 0 & 30 \\
\hline Control & 88 & 0 & 132 & 0 & 225 & 0 & 158 & 0 & 61 & 0 & 52 & 0 & 152 & 0 & 201 & 0 & 89 & 0 \\
\hline
\end{tabular}

$\mathrm{Bg}=\mathrm{B} \cdot$ glabrata

- - - - discontinued observations

$\mathrm{Bs}=\mathrm{B}$. straminea

FIGURE 1. Evolution of the Competitive Process in the Field Experiment During the Period 1981-1989. Alhandra, State of Paraíba, Brazil

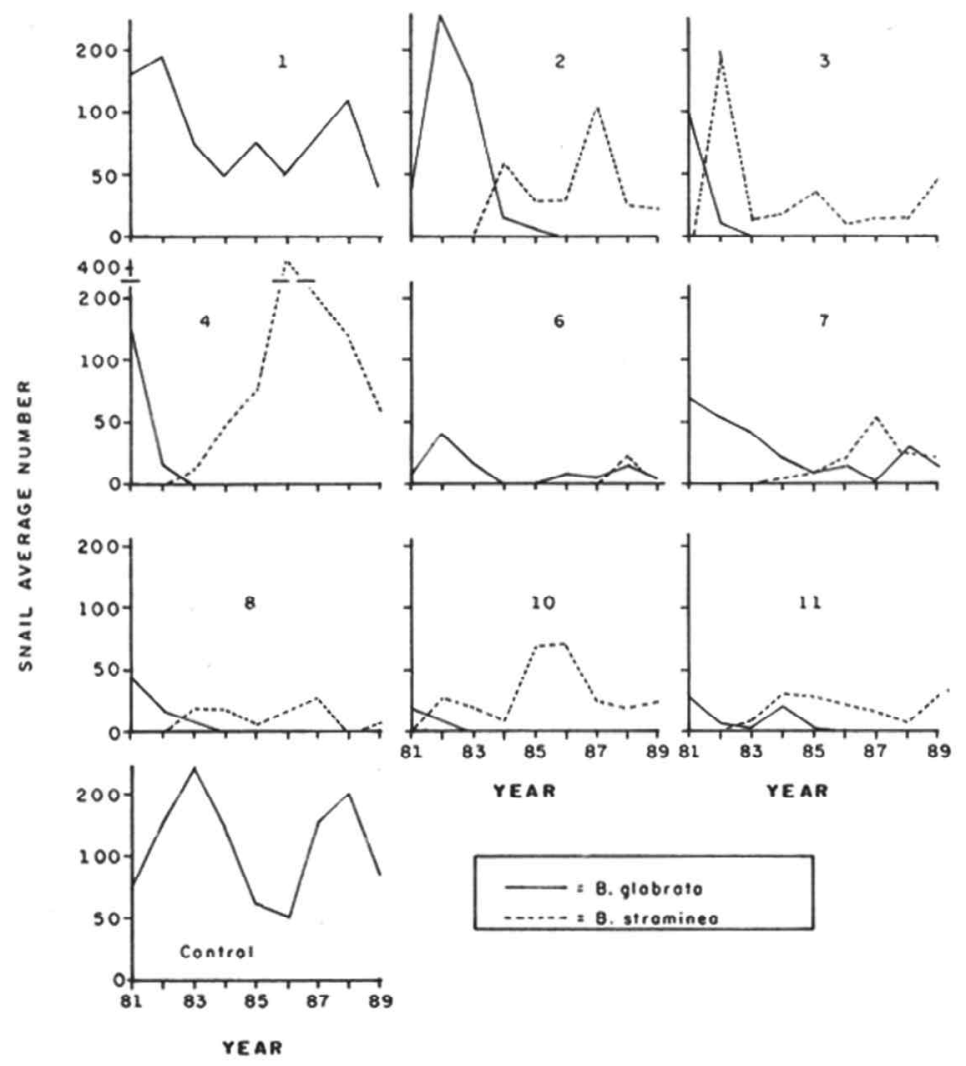


original snail (B. glabrata) population stocks replaced by the snail competitor $B$. straminea. In two of them (number 6 and 7) the $B$. straminea $\mathrm{x} B$. glabrata struggle remains. Finally, in the main stream (number 1) $B$. straminea had not any effect on the population of B. glabrata.

In the stream selected as control, the Popocas river, the original B. glabrata population shows ordinary breeding pattern.

\section{COMMENTS}

Results obtained in the current experiment show that the snail B. straminea has strong competitive advantages over $B$. glabrata. There is also evidence showing that seasonal dryness has marked influence on the phenomenon studied in the current paper.

In the six streams in which the native population of B. glabrata was totally excluded, the phenomenon occurred under different patterns. B. glabrata displacement was made at different periods of time, as follows: in streams number 3, 4 and 10, at the second year; in stream number 8 , at the fourth year; and in streams number 2 and 11, at the fifth year (Fig. 1).

During the rainy season most of the streams overflow, covering part of the area. During the dry season most of the streams dry up gradually. However, the dryness intensity varies from year to year, in time and space. Along the bed of some of the streams small pools are formed where mechanisms of competition are supposed to be very active.

There are only two permanent streams in the experimental area: the main stream (number 1) and the tributary stream number 6. All the others are subjected to the variable intensities of the seasonal dryness effects. This in part explains the variable responses occurring in the streams.

During the whole experiment $B$. glabrata was never found in the routine snail collections made in streams already dominated by the competitor snails, in spite of the fact that the introduction of $B$. straminea had been interrupted in the moment the stream was completely taken over by the competitor.

The higher competitive advantage of $B$. straminea in relation to $B$. glabrata has been attributed to various factors such as: vagility and aggressivity (Michelson \& Dubois, 1979; Barbosa et al., 1984); resistance to desiccation (Olivier \& Barbosa, 1956; Barbosa et al., 1985); locomotion speed and environmental exploratory capacity (Schall et al., 1986); and carrying capacity (Barbosa et al., 1992).

The above factors are probably due to higher genetic variations found in $B$. straminea when compared to other species of Biomphalaria (Woodruff et al., 1985). Genetic factors would be related to a better capacity of adaptation of $B$. straminea to diversified environments and, as a consequence, to confer this species better conditions for utilization of vital resources.

The invasion of B. straminea in Hong-Kong and its spreading over several territories in Southeast China revealed the strong colonization power of this species (Yipp, 1990).

Biological control is usually mentioned as an alternative method for the control of schistosomiasis. However, we are very far from having developed any effective biological method to control that disease.

The possibilities of the use of a $B$. straminea strain resistant to $S$. mansoni against $B$. glabrata are very limited. The main obstacle lays on the fact that the resistance developed in the laboratory would be diluted due to intraspecific crosses in the field inhabited by susceptible strains of that species.

It is believed, however, that a promissing research line is being open. Potentialities of the snail biological control have recently been emphasized by Michelson (1987) and Coimbra (1991). Attention should be particularly paid to the concept of snail control by genetic manipulation, first proposed 34 years ago by Hubendick (1958).

\section{ACKNOWLEDGMENTS}

This work was supported by the Financiadora de Projetos e Pesquisa (Finep), 
the Superintendência de Desenvolvimento do Nordeste (Sudene), the Conselho Nacional de Desenvolvimento Científico e Técnológico (CNPq), and the Agency for International Development, USA.

The authors thank Manoel Alexandre Neto and Barnabé José Tabosa for their technical assistance.

\section{RESUMO}

BARBOSA, C. S.; BARBOSA, F. S. \& ARRUDA, F. Estudo Experimental de Campo sobre a Competição entre Duas Espécies de Biomphalaria (Mollusca, Basommatophora), Vetores do Schistosoma mansoni no Nordeste do Brasil. Cad. Saúde Públ., Rio de Janeiro, 9 (2): 170-176, abr/jun, 1993.

Um estudo experimental de campo sobre a interação populacional entre Biomphalaria glabrata (população-alvo) e Biomphalaria straminea (competidor) foi realizado no município de Alhandra, PB, no período de 1980 a 1989.

Os resultados deste experimento nos levam a considerar que é possível a indução de um processo competitivo entre $B$. glabrata e $B$. straminea, uma vez que em nove dos criadouros trabalhados até o final, seis deles tiveram as populações da espécie endêmica totalmente substituídas pelo caramujo competidor.

O processo competitivo ocorreu mais eficazmente naqueles criadouros sujeitos à dessecação, o que parece ter favorecido a espécie competidora, que resiste bem mais aos períodos de seca.

Não houve regressão do processo, ou seja, em todos os riachos onde $B$. straminea se estabeleceu, o caramujo alvo não voltou a proliferar.

\section{Palavras-Chave: Biomphalaria;}

Esquistossomose; Controle Biológico; Comportamento Competitivo

\section{REFERENCES}

BARBOSA, C. S., 1992. Cultivo em massa de Biomphalaria straminea. In: Malacologia M édica. In Press.

BARBOSA-FIGUEIREDO, C. S., 1989a. Dispersão de B. straminea no estado de Sergipe: um estudo comparativo com dezenove anos de intervalo. Memórias do Instituto Oswaldo Cruz, 84: 383387.

, 1989b. Interações entre Espécies de Moluscos Transmissores da Esquistossomose Mansônica no Nordeste do Brasil. Tese de Mestrado, João Pessoa: Centro de Ciências Exatas e da Natureza, Universidade Federal da Paraíba.

BARBOSA, F. S., 1962. Aspects of the ecology of the intermediate hosts of Schistosoma mansoni interfering with the transmission of bilharziasis in Northeastern Brazil. Ciba Foundation Symposium on Bilharziasis, 23-25. Ed. J. \& A. Churchil Ltd. London, GB.

1973. Possible competitive displacement and evidence of hybridization between two Brazilian species of planorbid snails. Malacologia, 14: 401-408.

, 1981. New field observations on the competitive displacement between two species of planorbid snails inhabiting Northeastern Brazil. Memórias do Instituto Oswaldo Cruz, 76: 361366.

BARBOSA, F. S.; COSTA, D. P. \& ARRUDA, F., 1984. Competitive interactions between species of freshwater snails. I. Laboratory studies: Ib. Comparative studies of the dispersal and the vagility capabilities of Biomphalaria glabrata and B. straminea. Memórias do Instituto Oswaldo Cruz, 79: 163-167.

, 1985. Competitive interactions between species of freshwater snails. I. Laboratory studies. Ic. Comparative survival of Biomphalaria glabrata and B. straminea kept out of water. Memórias do Instituto Oswaldo Cruz, 80: 155157.

BARBOSA, F. S. \& FIGUEIREDO, T., 1969. Geographical distribution of the snail hosts of schistosomiasis mansoni in Northeastern Brazil. Revista do Instituto de Medicina Tropical de São Paulo, 2: 285-289.

BARBOSA, F. S. \& OLIVIER, L., 1958. Studies on the snail vectors of bilharziasis mansoni in North -eastern Brazil. Bulletin of the World Health Organization, 18: 895-908. 
BARBOSA, F. S.; SANCHEZ, O.; BARBOSA, C. S. \& ARRUDA, F., 1992. Dynamics of snail populations of Biomphalaria glabrata and B. straminea under semi-natural conditions. Cadernos de Saúde Pública, 8: 157-167.

COIMBRA Jr., C. E. A., 1991. Biological control for freshwater snails. Parasitology Today, 7: 124.

GUYARD, A. \& POINTIER, J. P., 1979. Faune malacologique dulçaquicole et vecteurs de la schistosomose intestinale en Martinique. Annales de Parasitologie Humaine et Comparée, 54: 193-205.

HUBENDICK, B., 1958. A possible method of schistosomiasis-vector control by competition between resistant and susceptible strains. Bulletin of the World Health Organization, 18: 11131116.

LUCENA, D. T., 1963. Planorbídeos transmissores da esquistossomose no Nordeste do Brasil. Revista Brasileira de Malariologia e Doenças Tropicais, 15: 16-26.

MEIER-BROOK, C. A., 1974. A snail intermediate host of Schistosoma mansoni introduced into Hong-Kong. Bulletin of the World Health Organization, 51: 661.

MICHELSON, E. H., 1987. The intermediate snailhost: an agenda for future study. Memórias do Instituto Oswaldo Cruz, 82 (Supl. IV): 193-195.

MICHELSON, E. H. \& DUBOIS, L., 1979. Competitive interactions between two snail hosts of Schistosoma mansoni: Laboratory studies on Biomphalaria glabrata and B. straminea. Revista do Instituto de Medicina Tropical de São Paulo, 21: 246-253.

OLIVIER, L. \& BARBOSA, F. S., 1955a. Seasonal studies on Australorbis glabratus (SAY) from two localities in Eastern Pernambuco, Brazil. Publicações Avulsas do Instituto Aggeu Magalhães, 4: 79-103.

, 1955b. Seasonal studies on Tropicorbis centimetralis in Northeastern Brazil. Publicações A vulsas do Instituto A ggeu Magalhães, 4: 105-115.

, 1956. Observations on vectors of schistosomiasis mansoni kept out of water in the laboratory. The Journal of Parasitology, 42: 277-286.
OLIVIER, L. \& SCHNEIDERMAN, M., 1956. A method for estimating the density of aquatic snail populations. Experimental Parasitology, 5: 109-117.

PARAENSE, W. L., 1977. Distribuição geográfica dos vetores da xistosomose no Nordeste do Brasil. In: Painel Programa Especial de Controle da Esquistossomose (P. A. Machado, coord.), pp. 311-315, Brasília: Ministério da Saúde. (VI Conferência Nacional da Saúde).

PARAENSE, W. L. \& DESLANDES, N., 1955. Studies on Australorbis glabratus. I: Biospecific characterization. II: Genetic status. Revista Brasileira de Biologia, 15: 341-348.

SCHALL, V. T.; JURBERG, P. \& ROZEMBERG, B., 1986. Orientation to the snail B. straminea in response to stimulation with ligth in a situation of selection. Memórias do Instituto Oswaldo Cruz, 81: 255-263.

TELES, H. M. S., 1988. Aspectos ecológicos de Biomphalaria Preston, 1910 (Basommatophora, Planorbidae) no Estado de São Paulo, Brasil. I. Sintopia. Ciência e Cultura, 40: 374-379.

WOODRUFF, D. S.; MULVEY, M. \& YIPP, M. W., 1985. Populations genetics of B. straminea in Hong-Kong. The Journal of Heredity, 76: 355360.

WRIGTH, C. A., 1968. Some views on biological control of trematode diseases. Transactions of the Royal Society of Tropical Medicine and Hygiene, 62: 320-324.

YIPP, M. W., 1990. Distribution of the schistosome vector snail Biomphalaria straminea (Pulmonata, Planorbidae) in Hong-Kong. The Journal of M olluscan Studies, 56: 47-55. 